\title{
Development Ability of Aerobic and Anaerobic Capacity on Children Age 6 to 12 Years Reviewed from Topography Link and Sex in District of Bima
}

\author{
$1^{\text {st }}$ Khairul Amar \\ STKIP Taman Siswa Bima \\ Bima, Indonesia \\ Amarsportscience281190@gmail.com
}

\begin{abstract}
This study aims to determine the development of aerobic and anaerobic capacity and capability in men and women aged 6 to 12 years living in the coastal areas. And also the comparison of aerobic and anaerobic capacity building capabilities of boys and girls at the age of 6 to 12 years living in the coastal areas with those living in mountainous areas of the Western Bima Nusa Regency. The research method used is the development research method of Cross-Sectional (research the developmental cross sectional). Average anaerobic capacity in boys in coastal areas. While the average aerobic capacity in boys in mountainous areas of age 6 years 19, age 7 years 23 , age 8 years 26, age 9 years 39, age 10 years 38, age 11 years 46 , and age 12 years 62 Average 128.2. Based on the results of this study can be concluded that the development of aerobic and anaerobic capacity capabilities both in coastal areas and in mountainous areas experienced a consistent development in each year. The average development of boys is high compared to women in the district of Bima.
\end{abstract}

Keywords- development of aerobics, anaerobic, children, topography, sex

\section{INTRODUCTION}

Physical development is one of the most important factors in the development of the individual as a whole. This physical ability affects the performance of individual movements that will lead to the achievement of sporting achievements. In achieving sporting achievements requires time and long-term coaching process, cannot be created and created in a short time, must be through the process of coaching conducted from an early age (children). Because in children functional ability can already be seen, especially on the development of big children. Large children are children between the ages of 6 to 10 or 12 years. Physical development of children that occurred during this period showed a different trend compared to the previous or after. The tendency that occurs is the pattern of apathy and growth patterns associated with the proportion of the size of body parts. Physical growth of boys and girls has begun to show tendency increasingly apparent [44]. In children aged 6 to 12 years there has been a development in terms of physical development, the development of biomotor components, including: strength, flexibility, endurance, power and other biomotor capabilities [13]. In addition to physical growth, in children aged 6 to 12 years, has been the process of increasing physiological maturity in each individual. The growth and level of physical and physiological maturity have an impact on the development of physical ability. Physical abilities of children, will affect the development of motion skills or increased exercise skills.

Sports coaching in children aged 6 to 12 years, other than based on physical conditions and some characteristics at a certain age, residential environment factors are also very important in the development of individual motion in exercising. Residential environments such as air temperature, climate, altitude, will have an impact on a person's physiological changes, the environment at which it will affect the physiological adaptation of a person [13]. One of the environmental adaptations can be made in comparison with the differences in partial pressure of oxygen (PO2), both in lowland and mountainous regions [12]. In addition distinguished coastal and mountainous areas in terms of air temperature and oxygen (O2) levels are also different [16]. The higher an area of sea level the oxygen $(\mathrm{O} 2)$ level is less. Given the differences in partial pressure of oxygen (PO2) found in lowland and mountainous areas, it will also affect the amount of hemoglobin $(\mathrm{Hb})$ in red blood cell granules. Mountainous areas or mountainous areas of oxygen $(\mathrm{O} 2)$ in the air will decrease. In order for the body to still get rations oxygen $(\mathrm{O} 2)$, then the propagation tool that is propagated, ie the number of hemoglobin $(\mathrm{Hb})$ in red blood cells will increase. In high areas such as the mountainous areas oxygen $(\mathrm{O} 2)$ and the pressure is smaller than the coastal areas or lowlands. Hence the need for physiological adaptation or acclimatization for people living in mountainous areas or in mountainous areas, this acclimation has occurred since birth.

Based on the above background, research will be conducted that aims to determine the development of aerobic and anaerobic capacity capability in boys and girls aged 6 to 12 years, influenced by the location of both topography in coastal areas and in mountain areas. Furthermore, it is to find out the comparison of aerobic and anaerobic capacity-building capabilities in boys and girls in the age group of 6 to 12 years, who were born and lived in coastal areas who would then be compared with boys and girls aged 6 to with 12 years, who was born and lived in a mountainous area. 


\section{MATERIALS AND METHOD}

This research is a developmental study with cross sectional method and comparative causal research. Developmental research is "focusing on the variables and their development over several periods [50]. This study investigates the patterns and subsistence of growth and development, and how the variables relate to one another and affect the properties of growth and development ".

The characteristics of developmental research are:

1. Know the development of research subjects within a certain time.

2. Can use longitudinal method and cross sectional method.

The method used in this developmental study is the crosssectional method which means that the researcher does not defend the research subject to be observed in the long run, but elicits new subjects replacing the old subjects, from various groups age. Long periods of time, replaced with sanding from different age groups.

The characteristics of this method are:

1. The researcher does not need to wait for long term of subject / child, so the research conclusion can be immediately known.

2. Research is able to control other variables because the implementation of short research.

3. A small possibility of losing a research subject.

While comparative causal research aims to investigate the possibility of causal relationships based on observation of the consequences and look for factors that may be the cause through certain data. Comparative causal research is ex post facto is a type of research conducted to examine one type of events that have occurred and then trace backward to determine the factors that can cause the incident [45]. This study uses the same basic logic with experimental research that if $\mathrm{x}$ then $\mathrm{y}$, only in this study there is no direct manipulation of independent variables (independent variables) because the phenomenon has occurred.

In addition, this research is known as research model "postevent measurement" (ex post facto) [1]. In this model the researcher does not provide treatment but estimates that one or more variables have been the cause of other variables. The study looked at causal relationships to variables that were seen as causal factors with the resultant variables.

\section{RESULTS AND DISCUSSION}

The focus area of this research is bima district of West Nusa Tenggara province. There are 18 sub-districts of Bima Regency: Sape Sub-district, Wera Sub-district, Belgo Subdistrict, District of Palibelo, Donggo Sub-district, Langgudu Sub-district, Lambu Sub-district, Bolo Subdistrict, Monta Subdistrict, Madapangga Sub-District, Lambitu District, Ambalawi District, studio of tambora sub-district. Sanggar and Tambora sub-districts are the sub-districts located the furthest from the administrative center of Bima regency, where the distance is about $130 \mathrm{~km}$ and $250 \mathrm{~km}$ respectively. In addition, these two sub-districts are the widest sub-districts in Kabupaten Bima with an area of $720 \mathrm{~km} 2$ and $505 \mathrm{~km} 2$ respectively. The capital of Donggo Sub-district, located in the village of O'o has a height of about $500 \mathrm{~m}$ above sea level. This makes Donggo District the sub-district with the highest altitude above sea level. In revealing the extent of the development process of the district sports bima, then taken 3 districts which became the focus area of research in order to represent the district of bima as a whole. The three sub-districts are meant to be advanced, medium and underdeveloped.

\section{A. Data Description}

Data descriptions include Aerobic capacity capability with Harvard Step Up test and Anaerobic capacity capability with Standing Broad Jump test, in boys and girls aged 6 to 12 years living in coastal and mountainous areas.

From the table 1, it can be seen the average aerobic and anaerobic capacity in boys and girls aged 6 to 12 years who live in mountainous areas.

Average aerobic capacity in boys in mountainous areas of age 6 years 19, age 7 years 23, age 8 years 26, age 9 years 39, age 10 years 38 , age 11 years 46 , and age 12 years 62 Average aerobic capacity in girls in mountainous areas 6 years of age 16 , age 7 years 18 , age 8 years 22 , age 9 years 30 , age 10 years 33 , age 11 years 42, and age 12 years 62. Average anaerobic capacity in boys in mountainous areas 6 years old 96.4, age 7 years 114.3, age 8 years 127.8 , age 9 years 141.8 , age 10 years 142.8, age 11 years 155.6, and age 12 years 158.1. Average anaerobic capacity in girls in mountainous areas of age 6 years 86.3 , age 7 years 100.9, age 8 years 105.7, age 9 years 116.1, age 10 years 119.6 , age 11 year 126.4, and age 12 years 128.2. Results of Data Analysis

Table 1. Descriptive Statistical Analysis Results Aerobic And Anaerobic Capacity Test In Ages 6 To 12 Years In The Mountain Region.

\begin{tabular}{|c|c|c|c|c|c|}
\hline \multirow{2}{*}{ No } & \multicolumn{5}{|c|}{ Mountains } \\
\cline { 2 - 6 } & age & \multicolumn{2}{|c|}{$\begin{array}{c}\text { Average } \\
\text { Aerobic } \\
\text { Capacity }\end{array}$} & \multicolumn{2}{c|}{$\begin{array}{c}\text { Average } \\
\text { Anaerobic } \\
\text { Capacity }\end{array}$} \\
\cline { 3 - 6 } & & Man & Women & Man & women \\
\hline 1 & 6 & 19 & 16 & 96,4 & 86,3 \\
\hline 2 & 7 & 23 & 18 & 114,3 & 100,9 \\
\hline 3 & 8 & 26 & 22 & 127,8 & 105,7 \\
\hline 4 & 9 & 36 & 30 & 141,8 & 116,1 \\
\hline 5 & 10 & 38 & 33 & 142,8 & 119,6 \\
\hline 6 & 11 & 46 & 42 & 155,6 & 126,4 \\
\hline 7 & 12 & 62 & 57 & 158,1 & 128,2 \\
\hline
\end{tabular}

\section{B. Development of Aerobic Capacity Capability}

The Capability Development of Aerobic Capacity In Boys And Girls at Ages 6 To 12 Years Living In Coastal Areas.

Complete below will present the development of aerobic capacity capability using the Harvard Step Up test on boys and girls aged 6 to 12 years living in coastal areas in the form of average yield tables and charts. 
Based on the above table average capacity of aerobic capacity of boys in the coastal area level 6 years of age 16, age 7 years 19 , age 8 years 21 , age 9 years 25 , age 10 years 33, age 11 years 41 , age 12 year 59 . While the average capacity of aerobic capacity of girls in coastal areas of age 6 years 14, age 7 years 15 , age 8 years 19 , age 9 years 22 , age 10 years 26, age 11 years 34, age 12 years 47 .

Average aerobic capacity capabilities in boys and girls aged 6 to 12 years living in coastal areas can be described in figure 1.

The graph above shows that the capacity of aerobic capacity in boys and girls aged 6 to 12 years living in the coastal areas is consistent. In children aged 6 years between men increased more than women. In children aged 7 years there is an increase in development that is not too large between men and women. At the age of 8 years there was a slight increase in men while women experienced a high increase. At the age of 9 years there is a large increase in boys and girls. At the age of 10 years there is a large increase in boys compared to women. In children aged 11 years there is a large increase in boys and girls. In children aged 12 years there is a considerable increase in development in boys and girls. The overall average capacity of aerobic capacity in boys living in coastal areas is higher than that of aerobic capacity in girls living in coastal areas.

Table 2. Average Aerobic Capacity of Men And Women On Coastal Coast.

\begin{tabular}{|c|c|c|c|c|c|}
\hline No & Age & $\begin{array}{c}\text { Man } \\
\text { (Fitness } \\
\text { Index) }\end{array}$ & $\begin{array}{c}\text { Women } \\
\text { (Fitnes } \\
\text { Index) }\end{array}$ & $\begin{array}{c}\text { Difference } \\
\text { Progress }\end{array}$ & $\begin{array}{c}\text { Percentage } \\
(\%)\end{array}$ \\
\hline 1 & 6 & 16 & 14 & 2 & $7 \%$ \\
\hline 2 & 7 & 19 & 15 & 4 & $12 \%$ \\
\hline 3 & 8 & 21 & 19 & 2 & $5 \%$ \\
\hline 4 & 9 & 25 & 22 & 3 & $6 \%$ \\
\hline 5 & 10 & 33 & 26 & 7 & $12 \%$ \\
\hline 6 & 11 & 41 & 34 & 7 & $9 \%$ \\
\hline 7 & 12 & 59 & 47 & 12 & $11 \%$ \\
\hline \hline \multicolumn{2}{|l}{ Average } & 31 & 25 & 5 & $9 \%$ \\
\hline
\end{tabular}

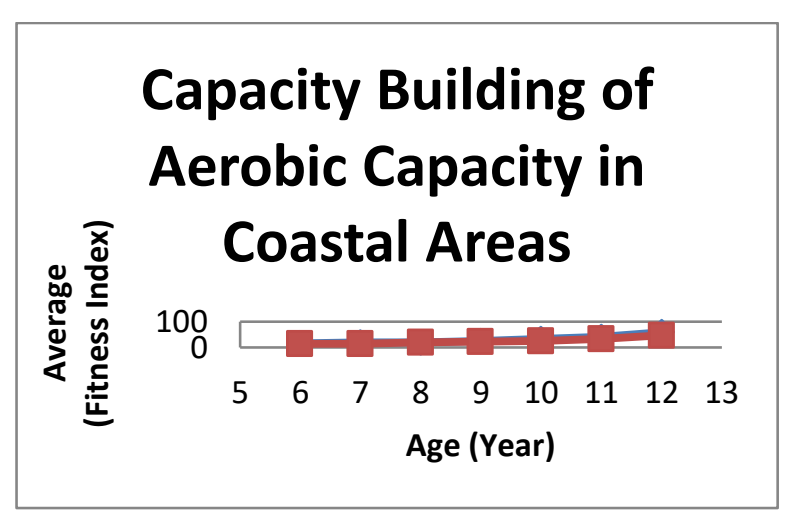

Fig. 1. Aerobic Capacity Capacity Development In Boys And Women Aged 6 To 12 Years Living In Coastal Areas.
C. Comparison of Aerobic Capacity Development Capacity In Boys And Women Aged 6 To 12 Years Living In Coastal Areas and Mountains.

Comparison of Aerobic Capacity Development Capacity In Boys Ages 6 To 12 Years Living In Coastal Areas With Living In The Mountains.

Complete below will be presented the development of aerobic capacity capability using the Harvard Step Up test on boys aged 6 to 12 years living in coastal areas with those living in mountain areas in the form of average yield tables and charts.

Based on the above table average capacity of aerobic capacity of boys in the coastal area level 6 years of age 16, age 7 years 19 , age 8 years 21 , age 9 years 25 , age 10 years 33, age 11 years 41 , age 12 year 59 . While the average aerobic capacity ability of boys in mountainous areas of age 6 years 19, age 7 years 23 , age 8 years 26 , age 9 years 36 , age 10 years 33 , age 11 years 46, age 12 year 62 .

Average aerobic capacity capability in boys aged 6 to 12 years living in coastal areas and mountain areas can be described in a graph as follows:

Table 3. Average Aerobic Capacity of Men in Coastal and Mountain Coast.
\begin{tabular}{|c|c|c|c|c|c|}
\hline No & Age & $\begin{array}{c}\text { Coastal } \\
\text { Coastal } \\
\text { Man } \\
\text { (Fitness } \\
\text { Index) }\end{array}$ & $\begin{array}{c}\text { Mountain } \\
\text { Man } \\
\text { (Fitness } \\
\text { Index) }\end{array}$ & $\begin{array}{c}\text { Difference } \\
\text { in } \\
\text { Progress }\end{array}$ & $\begin{array}{c}\text { Percentage } \\
(\%)\end{array}$ \\
\hline 1 & 6 & 16 & 19 & 3 & $9 \%$ \\
\hline 2 & 7 & 19 & 23 & 4 & $10 \%$ \\
\hline 3 & 8 & 21 & 26 & 5 & $11 \%$ \\
\hline 4 & 9 & 25 & 36 & 11 & $18 \%$ \\
\hline 5 & 10 & 33 & 38 & 5 & $7 \%$ \\
\hline 6 & 11 & 41 & 46 & 5 & $6 \%$ \\
\hline 7 & 12 & 59 & 62 & 3 & $2 \%$ \\
\hline \hline average & 31 & 36 & 5 & $9 \%$ \\
\hline
\end{tabular}

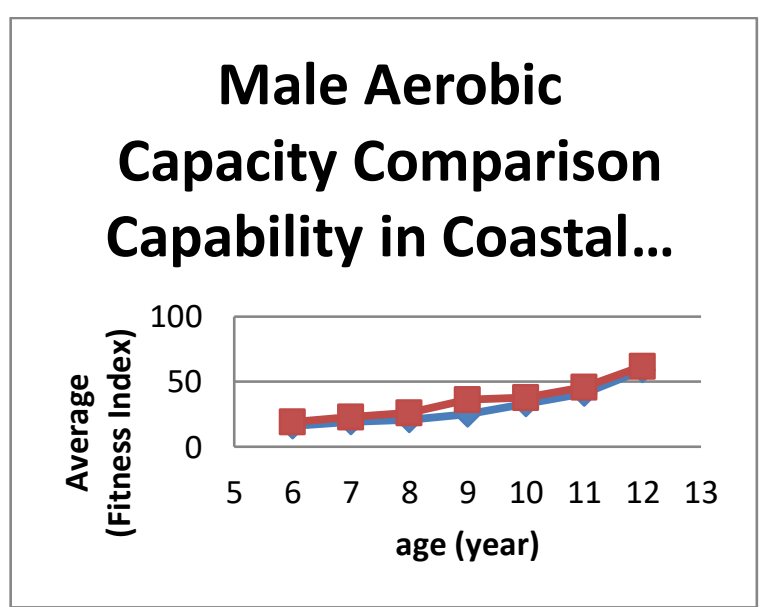

Fig. 2. Aerobic Capacity Development Capabilities In the Boys Age 6 Up To 12 Years Live At Regional and Local Coastal Mountains.

The graph above shows that the ability of aerobic capacity in boys aged 6 to 12 years who live in coastal areas and 
mountainous regions experiencing consistent growth. In children aged 6 years the mountains have increased not too large as well as children in coastal areas. In children aged 7 years the mountain area has increased not too big as well as coastal areas. In children aged 8 years there is an increase that is not too large as well as children coastal areas. In 9-year-old children, mountainous areas have a large increase whereas coastal children are experiencing not too large increase. At the age of 10 years the mountainous area is not too big increase, while the coastal children have a great increase. In 11-year-old children, mountainous areas have a large increase as well as in coastal children. In 12-year-old children, mountainous areas have increased considerable development as well as coastal children. The average overall ability of aerobic capacity in boys who live in the mountainous regions is higher than on the ability of aerobic capacity in boys who live in coastal areas.

\section{The Development of Anaerobic Capacity}

The Development of Anaerobic Capacity In Boys And Women Aged 6 To 12 Years Living In Coastal Areas.

Table 4. Average Capability Anaerobic Capacity Men And Women In Daytona Beach.

\begin{tabular}{|c|c|c|c|c|c|}
\hline No & Age & $\begin{array}{c}\text { Man } \\
(\mathrm{cm})\end{array}$ & $\begin{array}{c}\text { Women } \\
(\mathrm{Cm})\end{array}$ & $\begin{array}{c}\text { Difference } \\
\text { in } \\
\text { Progress }\end{array}$ & $\begin{array}{c}\text { Percentage } \\
(\%)\end{array}$ \\
\hline 1 & 6 & 93,2 & 85,8 & 7,4 & $4 \%$ \\
\hline 2 & 7 & 95,1 & 88,6 & 6,5 & $4 \%$ \\
\hline 3 & 8 & 117,2 & 98 & 19,2 & $9 \%$ \\
\hline 4 & 9 & 133 & 105,8 & 27,2 & $11 \%$ \\
\hline 5 & 10 & 138,6 & 110 & 28,6 & $12 \%$ \\
\hline 6 & 11 & 139,1 & 121,1 & 18 & $7 \%$ \\
\hline 7 & 12 & 141,7 & 123 & 18,7 & $7 \%$ \\
\hline \hline \multicolumn{2}{|l|}{ Average } & 123 & 105 & 18 & $8 \%$ \\
\hline
\end{tabular}

\section{Capacity Building of Anaerobic Capacity in Coastal AreasCapacity Building of...}

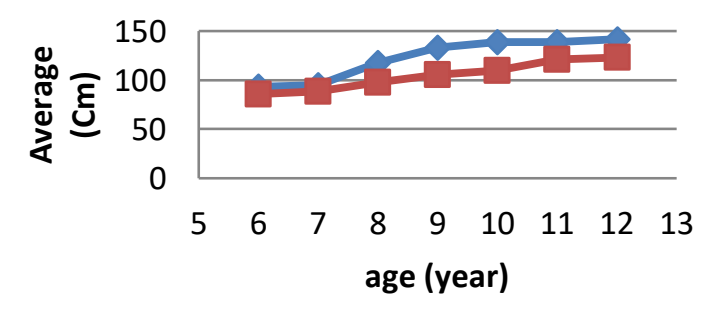

Fig. 3. The Development of Anaerobic Capacity Capacity In Boys And Women Aged 6 To 12 Years Living In Coastal Areas.
Complete below will present an anaerobic capacity building capability using the Standing Broad Jump test on boys and girls aged 6 to 12 years living in coastal areas in the form of average yield tables and charts.

Based on the above table the average anaerobic capacity ability of boys in the coastal area of 6 years age 93.2, age 7 years 95.1, age 8 years 117.2, age 9 years 135 , age 10 years 138.6 , age 11 years 139.1 , age 12 years 141.7 . While the average capacity of anaerobic capacity of girls in coastal areas of 6 years age 85.8 , age 7 years 88.6 , age 8 years 98 , age 9 years 105.8 , age 10 years 110 , age 11 years 121 , age 12 years 123 .

The chart above shows that anaerobic capacity abilities in boys and girls aged 6 to 12 years living in coastal areas are consistent. In children aged 6 years men have increased more than women. In children aged 7 years there is an increase in development that is not too large between men and women. At the age of 8 years there is a high increase in men while women experience a not too high increase. At the age of 9 years there is a large increase in boys and girls. At the age of 10 years there is a large increase in boys compared to women. In children aged 11 years there is a small increase in boys and girls experienced a high increase. In children aged 12 years there is an increase in small development in boys and girls. The overall mean capacity of anaerobic capacity in boys living in coastal areas is higher than in anaerobic capacity abilities in girls living in coastal areas.

\section{E. Comparison of Capacity Development of Anaerobic Capacity In Boys And Women Age 6 Up To 12 Years Living In Coastal Areas Of The Coast And Mountains.}

Comparison of Capacity Development of Anaerobic Capacity In Boys Ages 6 To 12 Years Living In Coastal Areas With Living In The Mountains.

Complete below will present an anaerobic capacity building capability using the Standing Broad Jump test in boys aged 6 to 12 years living in coastal areas with those living in mountain areas in the form of average yield tables and graphs.

Table 5. Average Capability of Anaerobic Capacity of Men in Coastal and Mountain Coast.

\begin{tabular}{|c|c|c|c|c|c|}
\hline No & Age & $\begin{array}{c}\text { Beach } \\
(\mathrm{Cm})\end{array}$ & $\begin{array}{c}\text { Mountain } \\
\text { Man } \\
(\mathrm{Cm})\end{array}$ & $\begin{array}{c}\text { Difference } \\
\text { Development }\end{array}$ & $\begin{array}{c}\text { Percentage } \\
(\%)\end{array}$ \\
\hline 1 & 6 & 93,2 & 96,4 & 3,2 & $2 \%$ \\
\hline 2 & 7 & 95,1 & 114,3 & 19,2 & $9 \%$ \\
\hline 3 & 8 & 117,2 & 127,8 & 10,6 & $4 \%$ \\
\hline 4 & 9 & 133 & 141,8 & 8,8 & $3 \%$ \\
\hline 5 & 10 & 138,6 & 142,8 & 4,2 & $1 \%$ \\
\hline 6 & 11 & 139,1 & 155,6 & 16,5 & $6 \%$ \\
\hline 7 & 12 & 141,7 & 158,1 & 16,4 & $5 \%$ \\
\hline \hline \multicolumn{2}{|l|}{ Average } & 123 & 134 & 11 & $4 \%$ \\
\hline
\end{tabular}




\section{Comparison of Capability of Male Anaerobic Capacity...}

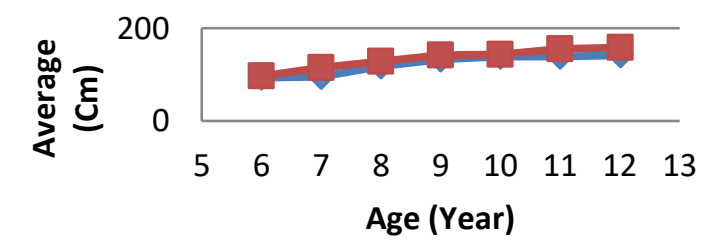

Fig. 4. The Development of Anaerobic Capacity Capacity in Boys Ages 6 to 12 Years Living In Coastal Areas And Mountains.

Based on the above table the average anaerobic capacity capability of boys in the coastal area of 6 years 93,2 , age 7 years 95.1 , age 8 years 117.2 , age 9 years 133 , age 10 years 138.6 , age 11 years 139.1, age 12 years 141.7. While the average anaerobic capacity of boys in the mountains was 6 years old 96.4 , age 7 years 114.3 , age 8 years 127.8, age 9 years 141.8 , age 10 years 142.8 , age 11 years 155.6, age 12 years 158.1 .

The average anaerobic capacity capability of boys aged 6 to 12 years living in coastal and mountainous areas can be described in a graph as follows:

The graph above shows that anaerobic capacity abilities in boys aged 6 to 12 years living in coastal and mountainous areas have consistent progress. In children aged 6 years the mountains have increased not too large as well as children in coastal areas. In children aged 7 years, mountainous areas have a large increase whereas coastal areas have a small increase. In children aged 8 years there is a large increase as well as children of coastal areas have increased greatly. In 9-year-old children, mountainous areas have a large increase as children of coastal areas have increased considerably. At the age of 10 years, the mountainous area is not too big, so the coastal children have a small increase. In 11-year-old children, mountainous areas have a large increase whereas in coastal children have a small increase. In 12-year-old children, mountainous areas have increased small development as well as coastal children. The overall average capacity of anaerobic capacity in boys living in mountainous areas is higher than in anaerobic capacity capacity for boys living in the coastal areas.

\section{CONCLUSION}

Based on the results of research and discussion that have been described in the previous chapter it can be drawn some conclusions as follows:

\section{A. Aerobic Capacity Capacity of Ages 6 to 12 Years in Coastal Areas and Mountains Areas.}

The development of aerobic capacity capability in boys and girls aged 6 to 12 years living in the coastal areas.

The development of aerobic capacity capability of boys and girls aged 6 to 12 years living in the coastal areas has increased quite steadily in each year. The average capacity of aerobic capacity in boys living in coastal areas is higher than that of aerobic capacity in girls living in coastal areas.

The development of aerobic capacity capability in boys and girls aged 6 to 12 years living in mountain areas.

The development of aerobic capacity capability of boys and girls aged 6 to 12 years living in mountainous regions has increased quite steadily in each year. The average aerobic capacity capability of boys living in mountainous areas is higher than that of aerobic capacity in girls living in mountainous areas.

Comparison of aerobic capacity-building capabilities of boys and girls at 6 to 12 years living in coastal areas with those living in mountain areas.

Capacity of aerobic capacity in boys aged 6 to 12 years living in coastal and mountainous areas has consistent progress. The average aerobic capacity capability of boys living in mountainous areas is higher than that of aerobic capacity in boys living in coastal areas. Capacity of aerobic capacity in girls aged 6 to 12 years living in coastal and mountainous areas has consistent progress. The average capacity of aerobic capacity in girls living in mountainous areas is higher than that of aerobic capacity in girls living in coastal areas.

\section{B. Capacity Building of Anaerobic Capacity of Ages 6 to 12 Years in Coastal Areas of Coastal and Mountain Areas.}

The development of anaerobic capacity abilities in boys and girls aged 6 to 12 years living in the coastal areas.

The development of anaerobic capacity capability of children aged 6 to 12 years living in the coastal areas has increased quite steadily in each year. The mean anaerobic capacity capability of boys living in coastal areas is higher than the anaerobic capacity capability of girls living in the coastal areas.

The development of anaerobic capacity capability in boys and girls aged 6 to 12 years living in mountainous areas.

The development of anaerobic capacity capability of children aged 6 to 12 years who live in mountainous areas has increased quite steadily in each year. The mean anaerobic capacity capability of boys living in mountainous areas is higher than the anaerobic capacity capability of girls living in mountainous areas.

Comparison of anaerobic capability of boys and girls at the age of 6 to 12 years living in the coastal areas with those living in mountainous areas.

Anaerobic capacity abilities in boys aged 6 to 12 years living in coastal and mountainous areas have consistent progress. The mean anaerobic capacity capability of boys living in mountainous areas is higher than the anaerobic capacity capability of boys living in the coastal areas. Anaerobic capacity abilities in girls aged 6 to 12 years living in coastal and mountainous areas are consistent. The mean anaerobic capacity capability of girls living in mountainous areas is higher than the anaerobic capacity capability of girls living in the coastal areas. 


\section{REFERENCES}

[1] Arikunto, Suharsimin. 2005. "Research Management," IEEE Transl. Manajemen Penelitian. Jakarta : PT RINEKA CIPTA.

[2] Astrand PO, Rodahl K, 1986. Texbook of Work Physiology, 3rd Ed., New York: McGraw Hill Book Co., Pp. 217-238, 296-340,355-383.

[3] Bompa, O Tudor. 1998. Theory and Methodologi of Training The Key To Athletic Perpomance. Dubuque lowa : kendaII/I luns Publishing Company.

[4] Badan Pusat Statistik. 2008. Human Development Index. (http://www.bps.go.id/ sector/ipm/index.html.).

[5] BPS. 2014. Kabupaten Bima dalam angka, Kabupaten Bima. Badan Pusat Statistik.

[6] Departemen Pendidikan Nasional, 2006. "Guideline for elementary school of national sport match year 2006," IEEE Transl. Pedoman Lomba/Pertandingan Olahraga Siswa Sekolah Dasar tingkat Nasional tahun 2006. Jakarta : Direktorat Jendral Manajemen Pendidikan Dasar Dan Menengah Direktorat Pembinaan Taman Anak-anak Dan Sekolah Dasar.

[7] Doewes, M. 2008. "Capacity of physical activity," IEEE Transl. Kapasitas Kerja Fisik. Sports Science Jurnal Ilmu Keolahragaan Vol 1 No. 1

[8] Faisal Yunus, 1997. "Pneumo physiology and sport," IEEE Transl. Faal Paru Dan Olahraga. Jakarta : Jurnal Respirasi Indonesia.

[9] Furqon. 1995. "General exercise theory," IEEE Transl. Teori Umum Latihan. Surakarta : Universitas Sebelas Maret Perss.

[10] Foss, Merle L., 1998. Physiogical Basis for Exercise and Sport. New York: The McGraw Companies, Inc.

[11] Fox, E. L., dan D. L. Costill, 1972. Estimated Cardiorespiratory Responses During Marathon Running. Arch Environ Health. 24:315-324.

[12] Fox EL and Bower WR. 1993. The Phisiological Basic For Exercise And Sport 5th Ed . WBC : Brown \& Bencmark Publisher.

[13] Gallahue, D.L., dan Ozmun, J. C.1998. Understanding Motor Development Infant Children, Adolescent, Adults. USA : Mac Graw Hill Company.

[14] Ganong WF. 1999. Review of Medical Physiology, New Jersey: Printice Hall.

[15] Groppel, Jack I, 1989. Science Of Choaching Tenms United States Of Amerika. Amerika : United Setates Asociation.

[16] Guyton A.C dan Hall John E. 1997. "Medical physiology," IEEE Transl. Fisiologi Kedokteran. Terjemahan Irawati Setiawan. Jakarta : EGC.

[17] Guyton A.C, 1983. "Medical physiology," IEEE Transl. Fisilogi Kedokteran, Jakarta : EGC.

[18] Haywood, K.M. 1986. Life Span Motor Development. University of Missouri. St. Louis : Human Kinetics Publishers.

[19] Junusul Hairy. 1989. "Sport Physiology," IEEE Transl. Fisiologi Olahraga. Jakarta : Departemen Pendidikan Dan Kebudayaan.

[20] Johnson Barry L \& Nellson Jack K., 1986. Practical Measurement for Evaluation Pysical Education, Minesota USA : Publising Company.

[21] Kathleen Liwijaya Kuntaraf dan Jonathan Kuntaraf. 1992. "Sport as health source," IEEE Transl. Olahraga Sumber Kesehatan. Bandung : advent Indonesia.

[22] Kirkendall DR. Gruber JJ. Jhonson RR. Measurement and Evolution For Phisical Educators . Lowa : Wm. C.Company Publiser, 1980.

[23] Klein, S., Coyle, E.F., and Wolfe. R.R., 1994. Fat metabolism during lowintensity exercise in endurance-trained and untrained men. Am. J. Phisiol. 267 (Endocrinol Metab. 30): E934-E940.

[24] Lamb. DR. 1984. Phisiology Basis Of Exercise Responses And Adaptions. Canada : Mac Milk Publishing Company.

[25] McArdle, WD. 1986. Exercise Physiology Energy, Nutrition and Human Performance. Philadelphia: Lear Febinger, pp. 80-123, 125-357
[26] M. Sajoto. 1995. "Improving and training of physic strength in sport," IEEE Transl. Peningkatan dan Pembinaan Kekuatan Kondisi Fisik Dalam olahraga. Semarang : Dahara Prize.

[27] Miller, S. 1978. The Facilitation of Fundamental Motor Skill Learning in Young Children. Unpublished Doctoral Disertation, Midhigan State University.

[28] Moeloek, Dangsina. 1984. "Basic physiology of sport and physical," IEEE Transl. Dasar Fisiologi Kesegaran Jasmani dan Fisik. Jakarta: FKUI.

[29] Mulyono B, 2007. "Test and measurement in sport," IEEE Transl. Tes dan Pengukuran Dalam Pendidikan Jasmani/Olahraga. Surakarta: Sebelas Maret University Press

[30] Nurhasan. 2005. "Practice guideline for sport," IEEE Transl. Petujuk Praktis Pendidikan Jasmani. Surabaya : UNESA Perss.

[31] Pate, Russell.R; Bruce McClenaghan; dan Robert Rotella,. 1984. Dasardasar Ilmiah Kepelatihan. Terjemahan Kasio Dwijowianto. Semarang : IKIP Semarang Press.

[32] Raven, P. 2000. "Anatomy atlas," IEEE Transl. Atlas Anatomi. Jakarta : Dejambatan

[33] Rushall BS, Pyke FS. 1990. A Training for Fitness, 1st ed. Melbourne: Macmillan Co. pp 5-26

[34] Sadoso Sumosardjuno. 1988. "Health practice knowledge in sport," IEEE Transl. Pengetahuan Praktis Kesehatan dalam Olahraga. Jakarta : PT Gramedia Pustaka Umum.

[35] Satimin Hadiwijaya. 2002. "Inferior extrimity," IEEE Transl. Ekstrimitas Inferior. Surakarta : Sebelas Maret University Press.

[36] Setijono, Hari. 2001. Fitnnes. Surabaya : Unesa University Press.

[37] Sharkey. 2003. "Sport and health," IEEE Transl. Kebugaran Dan Kesehatan. Jakarta : PT Raja Grapindopersada.

[38] Sudjana, 1999. "Experiment design and analysis," IEEE Transl. Disain dan Analisis Eksperimen. Bandung. Tarsito.

[39] Suharno.1993. "Research methode," IEEE Transl. Metodologi Pelatihan. Yogyakarta : IKIP Yogyakarta Press.

[40] Siswandari, 2006. "Computer based statistic," IEEE Transl. Statistik Berbasiskan Komputer. Surakarta : Diktat Statistik Program Pasca Sarjana Ilmu Keolahragaan.

[41] Sugiyanto. 2000. "Growth and move learning," IEEE Transl. Perkembangan dan Belajar Gerak. Jakarta : Depdikbud Universitas Terbuka.

[42] Sugianto, et al . "Basic training theory," IEEE Transl. Teori Kepelatiham Dasar. Jakarta : Lembaga Akreditasi Nasional Keolahragaan.

[43] Sugiyanto. 1993. "Growth and development," IEEE Transl. Pertumbuhan dan Perkembangan. Bahan Penataran Pelatihan Bulutangkis Tingkat Dasar Seluruh Indonesia. Bandung : KONI Pusat Dirjen Diklusepora PB PBSI.

[44] Sugiyanto. 1991. "Growth and move learning," IEEE Transl. Perkembangan dan Belajar Gerak. Jakarta : Depdikbud Universitas Terbuka.

[45] Sugiyono, 2004. "Business research methode," IEEE Transl. Metodologi Penelitian Bisnis. Bandung : CV ALFABETA

[46] Sukadiyanto. 2005. "Introduction of physical exercise theory and methode," IEEE Transl. Pengantar Teori dan Metode Latihan Fisik. Yogyakarta : Universitas Negri Yogyakarta

[47] Suryabrata, S. 2003 : 35. "Research methode," IEEE Transl. Metode Penelitian. Yogyakarta : UGM Press.

[48] Syaifudin. 1997. "Physiology for nursery," IEEE Transl. Fisiologi Untuk Perawat. Jakarta : EGC.

[49] Undang-Undang Republik Indonesia Nomor 3 Tahun 2005 Tentang Sistem Keolahragaan Nasional. Kementrian Negara Pemuda Dan Olahraga Republik Indonesia.

[50] Yatim Riyanto, 2001, "Education research methode," IEEE Transl. Metodologi Penelitian Pendidikan. Surabaya : SIC.

[51] Zainuddin M.1988. "Research methode," IEEE Transl. Metodologi Penelitian. Surabaya : Fakultas Farmasi UNAIR. 